\title{
HOLLOWING OUT AND REVITALISING A POST-SOCIALIST CITY CENTRE: VACANT COMMERCIAL PREMISES IN ZAGREB
}

\section{Petra Radeljak Kaufmann ${ }^{1}$ (D) Slaven Kliček ${ }^{2}$ - Filip Bišćević1^ ${ }^{1 \star}$ Dino Dokupil $^{1 \star}$ • Davorin Jašinski ${ }^{1 \star}$ • Marijan Begonja ${ }^{1 \star} \bullet$ Doroteja Harjač ${ }^{1 \star}$ - Tamara Bosanac ${ }^{1 \star}$ • Silvija Komes ${ }^{1 \star}$ - Lana Slavuj Borčić ${ }^{1}$ (D) Marko Stančec ${ }^{2} \cdot$ Mislav Zuanović $^{1 \star} \cdot$ Linda Korpar $^{1 \star}$}

${ }^{1}$ Department of Geography, Faculty of Science University of Zagreb

Marulićev trg 19, 10000 Zagreb: Croatia

e-mails: radeljak@geog.pmf.hr (corresponding author) • filip.biscevic@gmail.com • dino.dokupil@gmail.com • jasinski.davorin@gmail.com・begon.m@gmail.com・doroteja.harjac@gmail.com・tamarabosanac@outlook. com・silvija.komes@gmail.com・Islavuj@geog.pmf.hr・mislav.zuanovic@gmail.com・lindakorpar@gmail.com

${ }^{2}$ Association "Cyclists' Union"

Ribnjak 3, 10000 Zagreb: Croatia

e-mails: slaven.klicek@gmail.com・marko.stancec@gmail.com

\begin{abstract}
The problem of vacant commercial premises has been present in some central areas of transitional cities of Central and Eastern Europe, which have decayed in parallel to spatially uneven urban development processes and/or suburban expansion. This research aims to contribute to systematic analysis of the reasons for abandonment of commercial premises in the centre of Zagreb and exploration of revitalisation strategies, with an emphasis on the significance of citizen participation for successful planning and management of the city. The research was undertaken in two phases in May, 2016. The first included mapping of vacant commercial premises on selected streets in Zagreb's centre. Next, using a non-probabilistic sample, a questionnaire survey was carried out face-to-face and online $(N=200)$. The results of the questionnaire survey showed the respondents' awareness of the complex set of reasons underlying the occurrence and expansion of this phenomenon in the city centre and the need for urban regeneration, including a stronger regulatory framework at the city level.
\end{abstract}

\section{Key words}

vacant commercial premises - city centre $\bullet$ questionnaire survey $\bullet$ mapping $\bullet$ Zagreb

\footnotetext{
1 Authors marked with $\left({ }^{\star}\right)$ were students at the Department of Geography, Faculty of Science, University of Zagreb at the time the majority of the research work was done.
} 


\section{Introduction}

Vacant premises are a global issue that is present in diverse forms in cities in most industrial and especially post-industrial states, which has often called for specific interventions or approaches to revitalisation (Hall, 2002). The awareness regarding the threat posed to the vitality and viability of town and city centres by the exodus of retail, which has resulted in numerous vacant spaces instead of shops (Adams, Disberry, Hutchison, \& Munjoma, 2002; Gorter, Nijkamp, \& Klamer, 2003), has also led to specific regulatory measures (e.g. Gorter et al., 2003; Guimarães, 2018) and regeneration strategies.

This problem has characterised transitional cities of Central and Eastern Europe, in which some central areas have been allowed to decay in parallel to spatially uneven urban development processes and/or suburban expansion. This is related to a lack of proper tools that urban actors could use in housing renovation, brownfield redevelopment, infrastructure improvement, and historic preservation (Stanilov, 2007a). In Croatia, the problem has been magnified by the turbulent economic conditions of the last 30 years caused by the crisis of traditional industries in the 1980s, consequences of the 1991-1995 Croatian War of Independence (Homeland War), processes of transformation and privatisation within an ill-defined legal framework during the transition period, the global economic crisis of 2008, as well as the increasing emphasis on creating economic growth via orientation toward the service sector. The results of this are visible in the urban landscape, functional and physiognomic changes, and changes in the identity of cities in Croatia (See Jakovčić, 2006; Poljičak, 2014; Svirčić Gotovac, 2010; Tonković, 2015).

The problem of vacant spaces and approaches to urban regeneration in Zagreb have been examined from various angles, such as the influence of the process of retail decentralisation on business functions and premises in the city centre (Jakovčić, 2006), examples of projects aimed at revitalising urban areas (Hebar, 2016), similarities and differences in approaches to urban regeneration in Vienna and Zagreb (Jakovčić, Franz, \& Buzjak, 2016), and the social dimension of urban regeneration (Svirčić Gotovac, 2010). In the contemporary era, vacant spaces are being regarded with new interest, as a part of the concept of sustainable urban planning (Matković, 2016). The most important strategic development documents for Zagreb at the city administration level devote many pages to Zagreb's identity potential, cultural heritage, management of urban properties, and brownfield revitalisation (City of Zagreb, 2017 and 2012).

However, multiple questions emerge with regard to the present state and potential of vacant commercial spaces in the urban core. Should these spaces be revitalised? How? What should be the role of different actors in this process? Most importantly, how do citizens - creators and consumers of urban space - view the issue of vacant spaces? As noted by Scott \& Kühn (2012), regeneration in many cities of Central and Eastern Europe 'is conditioned by struggles to develop more decisive planning and policy frameworks with which to coordinate development processes' (p. 1103). Furthermore, it is important to take a deeper look into how local actors see potential for long-term regeneration strategies (Scott \& Kühn, 2012).

This research was conducted in two steps. First, a functional analysis of the vacant commercial premises on selected streets in the wider city centre of Zagreb was undertaken using mapping and field observations to determine the extent and the character of vacant spaces. Next, a questionnaire survey was undertaken with the intent to explore residents' views of the main reasons for the abandonment of commercial premises and potential for their revitalisation. Keeping in mind the challenges related to including stakeholders, where issues of power relations are also raised, a questionnaire survey potentially has a role of including "silent voices" and contributing to participatory decision-making (Damurski, Pluta, Maier, \& Andersen, 2019: 99). 
In the following sections, we examine the underlying reasons for abandonment of commercial premises and define revitalisation strategies with regard to citizen participation. After a description of research methods and the study area, the structure of vacant commercial premises on the researched streets is demonstrated. The following section presents attitudes of respondents in relation to the issue of vacant premises in Zagreb's city centre. The final section incorporates discussion and conclusion.

\section{The causes of abandonment of commercial premises}

A spectrum of processes have been affecting European cities with temporally and spatially differentiated effects, contributing to spread of vacant (commercial) spaces in the urban cores. Among the most notable ones is a trend of retail businesses relocating to cheaper, easier to reach locations on the edges of cities, which was observed in many (Western) European ${ }^{1}$ countries in the second half of the 20th century (Guy, 1998). As Gorter et al. (2003) noticed, several developments can be identified from the 1960s onwards that have made the city centre a less appealing shopping location than peripheral locations. Some examples are the decline in the accessibility of city centres, the lack of parking facilities, the shortage of shopping floor space (both quantitative and qualitative), increase in traffic congestion, increase of rent levels in city centres. The retail exodus towards suburban residential districts was also triggered by push factors such as rising population (as a result of suburbanisation processes), increasing spending capacity of consumers, and growing car ownership (Gorter et al., 2003). Spatial changes in the location of retail reflected the far-reaching transformation in the structure and organisation of retailing (Adams et al., 2002). This has been evident in the increasing size and

\footnotetext{
1 Apart from European countries, this process was present especially early in cities in North America.
}

diversification of firms, the increasing capitalisation of the industry and diversification of goods, the decreasing number of retailers, and the decreasing number but increasing size of shops (Adams et al., 2002; Gorter et. al, 2003). This resulted in appearance of hypermarkets in early 1960s (originating in France and spreading quickly to West Germany and the United Kingdom) and regional shopping centres on the edge of cities (e.g. in West Germany in the 1960s and 1970s, in the United Kingdom in the late 1980s, and in France, Spain, and Portugal in the 1990s) (Guy, 1998). Structural changes in the business model of retailing companies have been accompanied by significant changes in behaviour and priorities of consumers (Adams et al., 2002). The aforementioned changes affected post-socialist countries as well after 1989. The retail business sector is the fastest changing sector for most post-communist economies and consumer shopping behaviour and habits are changing in tune with this (Spilková, 2003; Križan, Bilková, Kita, \& Siviček, 2016). As Bilková, Križan, \& Barlík (2016) noticed, a notable bearer of changes in consumer habits was the construction of big shopping centers that were a novelty in shopping. Hypermarkets, specialised hypermarkets, and commercial centres came to be built on the outskirts of the city as well as in the city core, along thoroughfares and near important residential zones outside the city centre (Lukić \& Jakovčić, 2004; Nagy, 2001; Sić, 2007; Temelová, 2007). The shopping centres became a phenomenon, with both commercial and non-commercial purposes (Kunc \& Križan, 2018; Lukić \& Jakovčić, 2004). Going to the shopping centre became, besides shopping, an attraction, amusement, and leisure time activity (Kunc, Frantál, Szczyrba, Tonev, \& Toušek, 2011; Lukić, 2002; Spilková \& Radová, 2011). As living standards have improved, consumers generally spend a higher proportion of real disposable income on luxuries and a lower proportion on necessities, have high demands regarding quality of goods and shopping comfort and are likely to travel a greater distance to shop, 
usually by car (Adams et al., 2002; Trembošová, Dubcová, \& Kramáreková, 2014). Nevertheless, it should also be noted that economic development trends, with their impact on purchasing power, have affected the quantity of vacant commercial premises. For instance, Dolega \& Lord (2020) pointed to an increase in the average vacancy rate following the 2008 worldwide economic crisis.

Further retreat and decline of retail in urban core has been amplified by the recent rapid increase of online shopping which has significantly changed the way consumer goods are bought and sold. As Dolega \& Lord (2020) write, many traditional retail businesses have perished due to the rise of online sales, and e-commerce will have a most profound effect on the retail landscape. The e-commerce market in Central and Eastern Europe has also been developing dynamically in recent years (Kita, Szczyrba, Fiedor, \& Letal, 2017).

Overall, the different processes primarily present in Western European countries, along with more gradual adjustments in the urban patterns that developed during the second half of the 20th century, have taken hold in Central and Eastern European cities in a much shorter period of time (Stanilov, 2007b). Sýkora \& Bouzarovski (2012) pointed to previous research indicating the character of changes in the course of central and innercity urban restructuring in these cities, including the replacement of existing activities (primarily industry) with new uses, commercialisation, gentrification, the construction of new apartments, and brownfield regeneration. However, while the spatial restructuring of post-socialist cities brought about a general functional diversification and revitalisation of some urban districts, it was also often characterised by chaotic development patterns, rapid suburbanisation of population and functions, depopulation of city centres, and accelerated degradation of many areas (Keresztély \& Scott, 2012; Sić, 2007; Stanilov, 2007b). Thereby, in post-socialist countries, there were numerous specific problems inherited from the previous era. Temelová (2007) pointed to the lack of investment in maintaining and renewing existing buildings that characterised the socialist period, due to which the majority of Prague's inner city neighbourhoods entered the transition era with dilapidated buildings and neglected public spaces and infrastructure - a similar situation was present in most other post-socialist cities. Among the specific reasons for the closure of commercial spaces in city centres in countries that entered the transition era in the 1990s, Jakovčić (2006) listed the problem of unresolved ownership as a result of the process of de-nationalisation, along with opening the market to foreign shopping centres, hypermarkets, and other forms of retail businesses. Đokić (2010) also found the unresolved structure of ownership to be one of the main causes of growth in the number of unused and abandoned buildings in Croatia (as cited in Črnjar and Rodin, 2016).

Among the factors that can generally influence increases in the number of vacant spaces, the phenomenon of urban shrinkage, relating to considerable/constant loss of population in a given urban area, should be looked into more closely. It has been present throughout Europe, especially in parts of Central and Eastern Europe. The nature of this process and its causes and consequences for the affected urban areas are multifaceted; it differs spatially and temporally ${ }^{2}$ (Haase, Bernt, Großmann, Mykhnenko, \& Rink, 2013). Both the duration and intensity of population decline can vary (Hospers, 2014). There can also be spatial variation within a given city, whereby the inner-city areas have often experienced the most pronounced shrinkage (Haase et al., 2013). In this light, we should mention processes of depopulation and increases in the share of older population and single-member households that increasingly characterise

\footnotetext{
2 Haase et al. (2013) found three major drivers of urban shrinkage, which affected the ten cities in their study: economic decline and job losses; suburbanisation and changes in the settlement system; and natural population decline.
} 
historical city cores along the Croatian Littoral, along with losing the role of the main retail centres for their cities, while gaining a new characteristic: that of tourist centres (Poljičak, 2014). Research has shown a link between the decentralisation of retail, declining visits to the city core, and an impression of "emptiness" in the city centre outside of the peak tourist season (Tonković, 2015).

Still, the process of urban shrinkage can be generally looked at in relation to different phases of urban development. Dembski et al. (2019) refer to the Spatial Cycle Model by $V a n$ den Berg et al. (1982), noting that cities can be described as going through different stages in urban development, which are defined by centralisation and decentralisation of population in the context of functional urban regions.

\section{The revitalisation of city centres and citizen participation}

The manner of re-use of vacant (commercial) premises can be regarded with respect to wider revitalisation strategies of city centres, as well as the role of different stakeholders - especially the participation of citizens - in the urban governance processes. Dumbović Bilušić (2016), in relation to the planning of urban historic complexes/areas, defined urban regeneration as an umbrella term for urban restructuring, and more specifically as a process of reinstating development prosperity and returning useful purpose to areas that are characterised by urban, structural, functional, and sociological deterioration. The idea of regeneration is to introduce spatial, economic, social, and cultural changes into degraded areas to restore their social attributes (Kaczmarek, 2019). Regeneration differs from urban renewal, which is understood to include a group of planning measures and conditions for functional and qualitative changes of economic, social, cultural, and environmental issues in degraded areas, with emphasis on the physical aspect of renewal (Dumbović Bilušić, 2016). Depending on the recognised indicators of degraded areas, Doratli (2005) suggested different types of revitalisation, in terms of physical (refurbishment, conversion, demolition, and rehabilitation) and economic (restructuring, diversification, and regeneration) interventions and approaches. The Spatial Development Strategy of the Republic of Croatia (2017) describes urban transformation (of derelict/old industrial, military, and other complexes) and urban renovation (of settlements and urbanised areas). Various terms: urban reconstruction; revitalisation; regeneration; renewal; renovation; rehabilitation; reurbanisation; and recycling are all used with the goal of explaining the importance of rational use of space and functional restructuring of urban areas. Although certain differences are evident, these approaches advocate the relevance of multi-disciplinary implementation of revitalisation strategies, which respect spatial, conservation, sociological, economic, and ecological aspects of urban development (Dumbović Bilušić, 2016), and are based on clear methodology, financing, and long-term planning (Jukić, 2016).

Keeping in mind the terminological nuances, we use urban regeneration as an overall term for an integral outlook on the revitalisation of urban areas, whereby the issue of vacant premises in city centres also finds its place. Scott \& Kühn (2012) observed that a strategic, i.e. longterm and goal-oriented, approach to urban development was connected to urban regeneration, and that both regeneration and strategic planning were about the management of urban change and capacities to implement effective strategies to address specific problems. As noted by Ferretti \& Grosso (2019) in the case of abandoned buildings, deciding on the course of action can be seen as a complex decision-making problem, which includes dealing with multiple stakeholders' views and conflicting objectives (economic, environmental, or social), as well as with long timeframes which add further uncertainty to the decision-making process. Regeneration is affected by the actions of many layers of government and the decisions of different levels of public and/ 
or private actors in the context of urban governance (Jukić 2016; Petrić \& Mikulić 2009; Scott \& Kühn, 2012). As indicated by Kaczmarek (2019), a city, as a transforming space, can be defined through relationships among groups of users as well as links between the social and material structure.

People create emotional links to places (place attachment) and develop ideas, preferences, and values regarding the place they identify with (place identity) (Subiza-Pérez, Vozmediano, \& San Juan, 2020). Nagy (2001) noted that the city centre was generally seen as 'the focus of urban services, community life and identity' (p. 342). The main shopping area as (traditionally) an integral part of the city centre is therefore a focus of citizens' perceptions of urban space. Consequently, citizen participation in the adaptation of urban structures according to real-time needs (Strategija prostornog razvoja, 2017) can serve in underpinning different approaches to regeneration and a tool by which the balance between "old" and "new" functions is measured, along with the ability to find harmony in the application of new functions (Čaldarović \& Šarinić, 2009). Citizen participation, as was noticed by Damurski et al. (2019), has taken various forms, such as personal communication between the residents and the local authorities, public hearings, and open competitions, and all of them should have significant influence on the course of planning projects.

Different changes have been discussed in the context of the general post-socialist transformation of cities in Central and Eastern Europe. These include the increasing role of the private sector, an increase in entrepreneurial spirit among the population, and the greater involvement of the civil sector in urban planning and development. However, there has also been a general decline in the importance of urban planning, weakening of public administration in city management, absence of clear urban development strategies, lack of horizontal and vertical coordination between institutions and organisations, and stronger influence of social actors with financial (economic) power in comparison to civil actors and experts (lanoș, Sorensen, \& Merciu, 2017; Slavuj, Cvitanović, \& Prelogović, 2009; Stanilov, 2007b; Svirčić Gotovac, 2010; Sýkora \& Bouzarovski, 2012; Temelová, 2007; Tonković, 2015). Even in the case of fruitful processes of city centre revitalisation (the example of Ljubljana), Svirčić Gotovac \& Kerbler (2019) found that there was also no real citizen participation in this process, except at the formal planning level. Hence, diverse modes of effective citizen participation should be further explored, together with potential impacts on urban policies.

\section{Methods and study area}

The research was conducted in two phases. The first phase included mapping of vacant commercial premises in the study area, with the goal of identifying their quantity, previous use, and analysing the spatial and functional structure of streets with emphasis on abandoned and unused spaces. The mapping was conducted in the first half of May, 2016 and included four streets in Zagreb's city centre, noted for the presence of a large quantity of vacant premises. The streets in question are llica Street, Tratinska Street, Vlaška Street, and Knez Branimir Street (commonly and hereafter referred to as Ilica, Tratinska, Vlaška, and Branimirova). Ilica is the fourth-longest street in Zagreb $(5,653 \mathrm{~m})$, but this research focused on the section from the British Square (Britanski trg) to Črnomerec $(3,320 \mathrm{~m})$. The total lengths of Tratinska $(1,160 \mathrm{~m})$ and Vlaška $(2,065 \mathrm{~m})$ were mapped. Mapping of Branimirova was carried out on the section from the main train station to the intersection with Marin Držić Avenue $(1,450 \mathrm{~m})$; this section of the street is locally known as "Old Branimirova". Using mapping, data were collected regarding vacant premises on the ground floor of buildings along the researched street sections, as well as in courtyards that were accessible. Vacant spaces were categorised into seven categories: (1) retail businesses; (2) trade and craft shops (e.g. goldsmiths, shoemakers, clockmakers, seamstresses, and other small 
traditional workshops); (3) hospitality businesses; (4) professional and specialised services (e.g. electronics stores, tyre shops, house painters, glaziers); (5) personal services (hair dressers, cosmeticians, etc.); (6) other (industrial and rail infrastructure and objects); and (7) unknown (spaces where it was not possible to determine the previous function). After mapping, which was carried out on the basis of the cadastral plan, the data were digitalised and visualised using ArcGIS 10.3.1 software.

The second phase - and the central part of the research was a questionnaire survey, which was undertaken in May, 2016. A nonprobabilistic sample was used and the survey was carried out in two ways: face-to-face and online. The total number of respondents that took part in the survey was 200, whereby 101 surveys were collected using an online form that was distributed via social media. The other 99 questionnaires were collected in person with respondents encountered in the researched areas.

The questionnaire survey consisted of 13 questions, of which four were of the open-ended type. The first group of questions regarded the characteristics of the respondent: age; gender; place of residence; education level; and profession. According to gender, $42.0 \%$ of the respondents were male and $58.0 \%$ female. According to age structure, $16.0 \%$ of respondents were under the age of $20,64.5 \%$ were between the ages of 20 and $40,15 \%$ were between the ages of 40 and 60 , and $4.5 \%$ were over the age of 60 . Respondents were also categorised according to their place of residence in Zagreb, wherein 16 out of 17 neighbourhoods were represented (only Brezovica neighbourhood was not). According to level of education, $50.0 \%$ of the respondents had a university or college-level degree, $45.5 \%$ had a high school-level education, and $4.5 \%$ had a primary school-level education (to 8th grade). According to employment status, $49.0 \%$ of respondents were (university-level) students, $21.5 \%$ were employed, $10.5 \%$ were employed part-time, 9.0\% were unemployed, $5.5 \%$ were pensioners, and $4.0 \%$ were school pupils. The second group of questions related to the level of awareness regarding the problem of vacant spaces and of the circumstances under which they came to be vacated. The third group of questions aimed at exploring the frequency and reasons for visiting the researched streets, along with respondents' recollection of the businesses or functions that once occupied the vacant spaces in the research area. Finally, respondents were asked for their opinions regarding potential paths of future development for vacant spaces in the coming decade, as well as their preferred methods of revitalisation. Answers to open-ended questions were coded into corresponding categories. Data analysis was done using the SPSS Statistics program.

\section{Vacant commercial premises on researched streets}

Mapping of streets included in this research identified 206 vacant commercial premises. The largest number of premises was found on Ilica and Vlaška, followed by Tratinska, and finally Old Branimirova (Fig. 1). The average density of vacant premises was highest on Vlaška (35.8 premises per $\mathrm{km}$ ), then on Tratinska (28.5 premises per $\mathrm{km}$ ), llica (24.1 premises per km), and Old Branimirova (13.1 premises per $\mathrm{km}$ ).

Along Old Branimirova, 19 vacant commercial premises were mapped; all on the northern side of the street. The largest number of them were categorised as unknown (8) since they had mostly been vacant for a longer period of time, making it impossible to ascertain previous use. The second largest category was other (5). An example of Zagreb's derelict industrial heritage is found within this category3: the Nada Dimić factory. In the mapped area, 2 vacant retail

\footnotetext{
3 Since its construction, the factory has undergone many changes, including remodeling, upgrades, and change of investors, architects and builders. Currently it is in a state of decay (Pretković, 2015).
} 


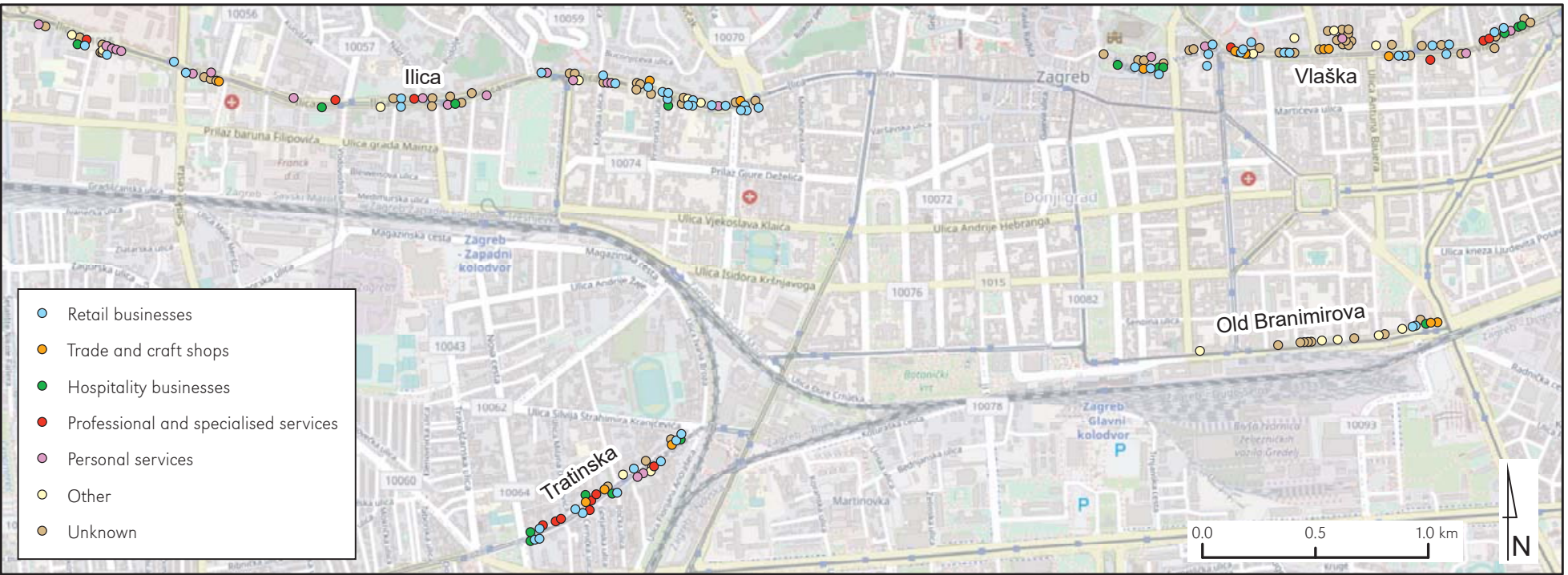

Figure 1. Vacant commercial premises on researched streets

Source: Layer - ArcGIS 10.3.1, Basemap, Open Street Map 
businesses, 2 trade and craft shops, 1 hospitality business, and 1 object for personal services were found. Almost a third of all vacant premises on Old Branimirova was found next to the Branimirova market, while the rest of vacant spaces were regularly distributed along the street.

A total of 80 vacant premises were mapped on llica from Črnomerec to the British Square. Premises were equally distributed on both sides of the street in the eastern part of Ilica, while in the western part they were found primarily on the southern side (in relation to the location of the Military Academy and the Catholic University). The largest number of vacant premises on Ilica also fell into the category unknown (26), followed by vacant retail businesses (22), and objects for personal services (16). Other categories were relatively small in number (4 vacant hospitality businesses, 3 professional and specialised objects, and 3 trade and craft shops). Category other included 6 objects. The highest concentration of vacant premises was located in the easternmost segment of the examined section of Ilica, closest to the central square in Zagreb, while the lowest concentration was found in its central part. It is worth mentioning here one of llica's interesting features: courtyards, which included several vacant spaces.

There were 74 vacant premises on Vlaška, most of them located on the northern side of the street. The most represented category was unknown (31), followed by vacant retail businesses (18). Furthermore, there were 6 vacant hospitality businesses, 6 vacant trade and craft shops, 5 vacant objects for personal services and 4 vacant objects for professional and specialised services. The category other included 4 premises, of which the Military Hospital stood out as the largest vacant facility on Vlaška4. Vacant spaces were equally represented along Vlaška; they were also located in (hidden) courtyards.

\footnotetext{
${ }^{4}$ After years of considering various ideas for the renovation of the Military Hospital, built in the mid19th century, a project of redevelopment into a school complex was begun in 2018.
}

On Tratinska, 33 vacant premises were mapped. The largest number were retail businesses (10), mostly clothing stores (4). There were 7 professional and specialised services, including auto parts shops, stores selling glass products, tools, ceramics, etc. They were followed by vacant hospitality businesses (5), objects of unknown previous use (4) and trade and craft shops (3), 2 of which were former clockmakers. There were 2 objects for personal services and 2 objects in the category other (including a former bank - the only facility on Tratinska that occupied more than 1 floor).

The mapping showed that vacant commercial premises were generally located on a single floor (with exceptions such as the Nada Dimić factory, which spans 4 floors), while buildings with vacant premises had between 1 and 6 floors. The ownership structure ${ }^{5}$ included properties owned by legal and natural persons, the Republic of Croatia, the City of Zagreb, and social ownership ${ }^{6}$.

\section{Respondents' attitudes about vacant premises}

Regarding the degree of familiarity with the issue of vacant commercial premises in Zagreb's centre, almost a half of the respondents $(49.0 \%)$ stated that they were somewhat familiar, $18.0 \%$ were unfamiliar, and $17.5 \%$ were neither familiar nor unfamiliar with the issue. Only $15.5 \%$ of the respondents were fully familiar with the issue.

The majority of respondents were of the opinion that the problem of vacant premises was present on the researched streets: $76.5 \%$ of respondents for the case of Ilica; $66.0 \%$ for Vlaška; 65.0\% for Old Branimirova; and

5 The ownership structure was analysed according to the State Geodetic Administration Geoportal, https://geoportal.dgu.hr/ and the Real Property Registration and Cadastre Joint Information System (Particle Survey), https://oss.uredjenazemlja.hr/public/index.jsp.

6 Social ownership is a form of ownership that dates back to the Socialist Federal Republic of Yugoslavia. In some cases, property ownership has never been resolved due to social ownership issues. This was, for example, represented on Tratinska. 
51.5\% for Tratinska7. Furthermore, $70.0 \%$ believed that the problem of vacant premises existed elsewhere in Zagreb ${ }^{8}$.

Respondents were asked to list reasons for the abandonment of commercial premises and these answers were coded separately. In total, there were 299 coded responses, and the share of each category was calculated according to the total number of respondents (Tab. 1). According to respondents, main reasons for abandonment were high rental prices, the economic and financial crisis, unemployment and decline in purchasing power, opening of shopping centres and new commercial premises - predominantly on the edge of the city - as well as difficulties and general unprofitability concerning business management and competition from outside the city centre. About 10\% of respondents stated the general decay of businesses and old trades, and politics and poor management at various levels (from state to city government) as reasons for the abandonment of commercial premises. Other somewhat frequent answers included problems related to transition, privatisation and propertyrelated legal issues, followed by high maintenance costs, lack of ideas and poor business management.

Selected examples of respondents' responses illustrate their views regarding why commercial premises were vacant:

'Because of the intent to gentrify, increase in rent for spaces, the disadvantaged position of entrepreneurs, craftsmen and the economy in general, poor legislation' (R-053);

'Because of large shopping centres which are too close to the city centre and available to everyone, and have become "urban" parks - people spend their whole afternoons

7 Shares of the answer "I don't know" were as follows: $46.5 \%$ for Tratinska; $32.0 \%$ for Old Branimirova; $23.0 \%$ for Vlaška; and $16.5 \%$ for Ilica. The percent of respondents who thought that the problem of vacant premises did not exist on those streets was as follows: 11.0\% for Vlaška; $7.0 \%$ for Ilica; 3.0\% for Old Branimirova; and $2.0 \%$ for Tratinska.

$813.0 \%$ of the respondents did not know or were not sure; $11.5 \%$ believed that this problem did not exist elsewhere; $5.5 \%$ did not provide answers. in them, and it has become easier to walk around in one large indoor area than smaller stores scattered throughout the city centre.' (R-090);

'Lack of interest for the services offered by previous tenants, decrease of values due to investors' lower repurchase prices, high risk and initial costs of starting a new business' (R-058);

'[C]losure of smaller trade and craft shops and retail stores due to unprofitability of business, death of craftsmen... larger chains have pushed out stores and certain crafts are dying out or cannot compete with someone larger' (R-044);

'Return of properties, especially to the elderly [...] In many cases like that, unrealistic rent prices, without agreement among multiple owners of a space [...] No urban strategy about what is needed in a neighbourhood in terms of economic activities [...] [The state] through its regulations made [small entrepreneurs and craftsmen] disappear from neighbourhoods, because they could no longer live from their work, and favoured larger [companies]' (R-055).

In keeping with the aforementioned, $73.5 \%$ of respondents agreed or fully agreed with the statement that a large number of vacant commercial premises were present in the centre of Zagreb. Among offered reasons for abandoning commercial premises, the greatest percentage of respondents agreed that the unfavourable economic situation in the country contributed to the increase of vacant premises $(80.0 \%$ agreed or fully agreed), as well as construction of large shopping centres outside the city centre $177.0 \%$ agreed or fully agreed), followed by the claim Former traditional trade and craft shops (shoemaker/tailor/clockmaker, etc.) cannot compete with contemporary market trends, so their individual services are not needed (63.0\% agreed or fully agreed). Slightly less than half of respondents (48.0\%) agreed or fully agreed that the increase in number of vacant commercial premises was also a consequence of citizens moving out of the city centre. Additionally, $63.5 \%$ of respondents agreed that 
Table 1. Reasons for abandonment of commercial premises in Zagreb's centre, stated by respondents*

\begin{tabular}{|l|c|c|}
\hline \multicolumn{1}{|c|}{ Reason } & $\begin{array}{c}\text { Number } \\
\text { of coded } \\
\text { answers }\end{array}$ & $\begin{array}{c}\% \text { of } \\
\text { respondents }\end{array}$ \\
\hline High rental prices & 58 & 29.0 \\
Economic and financial crisis, unemployment and decline in purchasing power & 43 & 21.5 \\
Opening of shopping centres and new commercial premises (on the edge of the city) & 38 & 19.0 \\
General (un)profitability and difficulties concerning business management and & 37 & 18.5 \\
competition & 22 & 11.0 \\
Decay of businesses and old crafts & 21 & 10.5 \\
Politics and poor management at various levels & 15 & 7.5 \\
The socio-economic transition and privatisation, property-related legal issues and & 13 & 6.5 \\
recovery of properties & 10 & 5.0 \\
High maintenance costs & 8 & 4.0 \\
Lack of ideas and poor business management & 6 & 3.0 \\
Emigration & 5 & 2.5 \\
Respondent did not know & 4 & 2.0 \\
Traffic inaccessibility and parking issues & 19 & 9.5 \\
Decrease in the number of citizens living in the city centre & 299 & \\
Other & & \\
\hline Total & 2.5 \\
\hline
\end{tabular}

* $4(2.0 \%)$ respondents did not provide answers

vacant commercial premises make the city centre less attractive for recreation, hospitality, and other services. Slightly under half of respondents agreed that the city centre no longer has the role of social meeting place like it once had (48.0\%) (Tab. 2).

An overwhelming majority (92.0\%) of respondents agreed or fully agreed that revitalisation of vacant premises contributed to the development of tourism in Zagreb, and $77.0 \%$ agreed that diversification of services and activities would attract visitors to the city centre. Only $6.5 \%$ of respondents believed that vacant spaces should not be redeveloped and revitalised and $78.5 \%$ of respondents believed that vacant and unused premises are a problem that city authorities should address as a priority.

The following questions specifically addressed the researched streets. The results show that llica (between British Square and Črnomerec) and Vlaška were more frequently visited than Tratinska and Old Branimirova (Fig. 2). All four streets were mostly visited only "in transit". Regarding other reasons for visiting, retail, entertainment and recreation, and other purposes were somewhat more common (Fig. 3).

Less than one-third (32.0\%) of the respondents reported they remembered the researched streets for their former activities or use. Among these functions, they mentioned retail stores (especially the ones offering clothing and footwear or electronics - for example, on Vlaška, there was 'a store that sold everything (from a needle to an anchor), where I bought small electronics [...]' R-052). They also remembered small traditional trade and craft shops such as shoemakers, tailors, clockmakers, woodcarvers, umbrella repairmen, leatherworkers, quilters, hatters, goldsmiths, hairdressers, musical instrument builders, wood turners, tinsmiths, locksmiths, handymen, etc. They mentioned hospitality functions: restaurants; pizzerias; and confectioneries. Branimirova reminded some of the respondents of its former industrial function. 
Table 2. Reasons for abandoning commercial premises and their potential in Zagreb's centre

\begin{tabular}{|c|c|c|c|c|c|c|c|}
\hline Reason & 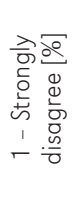 & 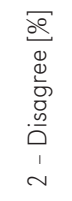 & 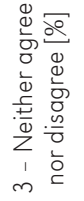 & 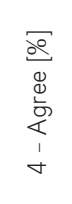 & 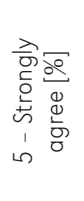 & $\Sigma$ & 只 \\
\hline $\begin{array}{l}\text { There is a large number of vacant commercial } \\
\text { premises/stores in Zagreb's centre. }\end{array}$ & 0.0 & 3.5 & 23.0 & 38.0 & 35.5 & 4.06 & 0.852 \\
\hline $\begin{array}{l}\text { The construction of large shopping centres outside } \\
\text { the city centre had a major impact on the increase } \\
\text { in the number of vacant commercial premises. }\end{array}$ & 1.5 & 5.5 & 16.0 & 36.0 & 41.0 & 4.10 & 0.959 \\
\hline $\begin{array}{l}\text { Former traditional trade and craft shops (shoe- } \\
\text { maker/tailor/clockmaker, etc.) cannot compete with } \\
\text { contemporary market trends, so their individual } \\
\text { services are not needed. }\end{array}$ & 7.0 & 8.5 & 21.5 & 35.5 & 27.5 & 3.68 & 1.168 \\
\hline $\begin{array}{l}\text { The unfavourable economic situation in the country } \\
\text { contributes to the increase in the number of vacant } \\
\text { commercial premises. }\end{array}$ & 2.0 & 4.0 & 14.0 & 33.0 & 47.0 & 4.19 & 0.958 \\
\hline $\begin{array}{l}\text { The increase in number of vacant commercial } \\
\text { premises is also a consequence of citizens moving } \\
\text { out of the city centre. }\end{array}$ & 6.5 & 18.0 & 27.5 & 30.5 & 17.5 & 3.35 & 1.154 \\
\hline $\begin{array}{l}\text { Vacant commercial premises and former trade } \\
\text { and craft shops in the city centre make this area } \\
\text { less attractive for recreation, hospitality, and other } \\
\text { services. }\end{array}$ & 3.0 & 11.0 & 22.5 & 42.0 & 21.5 & 3.68 & 1.026 \\
\hline $\begin{array}{l}\text { The city centre no longer has the role of social } \\
\text { meeting place like it once had. }\end{array}$ & 6.0 & 20.0 & 26.0 & 29.0 & 19.0 & 3.35 & 1.172 \\
\hline $\begin{array}{l}\text { Diversification of services and activities in the area } \\
\text { of vacant premises would attract visitors to the city } \\
\text { centre. }\end{array}$ & 1.5 & 6.0 & 15.5 & 43.0 & 34.0 & 4.02 & 0.935 \\
\hline $\begin{array}{l}\text { Revitalising vacant premises contributes to devel- } \\
\text { opment of tourism in the city of Zagreb. }\end{array}$ & 1.5 & 2.0 & 4.5 & 41.5 & 50.5 & 4.38 & 0.792 \\
\hline $\begin{array}{l}\text { Vacant premises do not need to be redeveloped } \\
\text { and revitalised as they are not of significant urban } \\
\text { value. }\end{array}$ & 59.5 & 25.5 & 8.5 & 4.5 & 2.0 & 1.64 & 0.957 \\
\hline $\begin{array}{l}\text { Vacant and unused commercial premises and for- } \\
\text { mer trade and craft shops are a problem that city } \\
\text { authorities should address as a matter of priority. }\end{array}$ & 0.5 & 6.0 & 15.0 & 35.5 & 43.0 & 4.15 & 0.921 \\
\hline
\end{tabular}

In answer to the question of what would happen to the aforementioned vacant commercial premises in the following 10 years, $36.5 \%$ of respondents did not expect any significant changes (Tab. 3). They believed that vacant premises would continue to physically deteriorate or that the number of such properties would increase. This can be seen in the following statements: 'The majority of them will probably stay vacant' (R-059); 'They will keep deteriorating, with chunks of plaster falling on pedestrians' (R-102), 'Nobody will renovate them because it is too much work to renovate everything, and it doesn't make any sense to renovate only one' (R-184).

Part of the respondents (10.5\%) expected them to stagnate or keep falling into disrepair, unless revitalisation measures were taken: ' $[T]$ he process of abandoning will intensify unless incentive measures are introduced, that is, unless the City contributes to revitalisation' (R-097); 'They will keep lagging behind and become vacated. However, should a private investor turn up, redevelopment of spaces is possible' (R-105). 


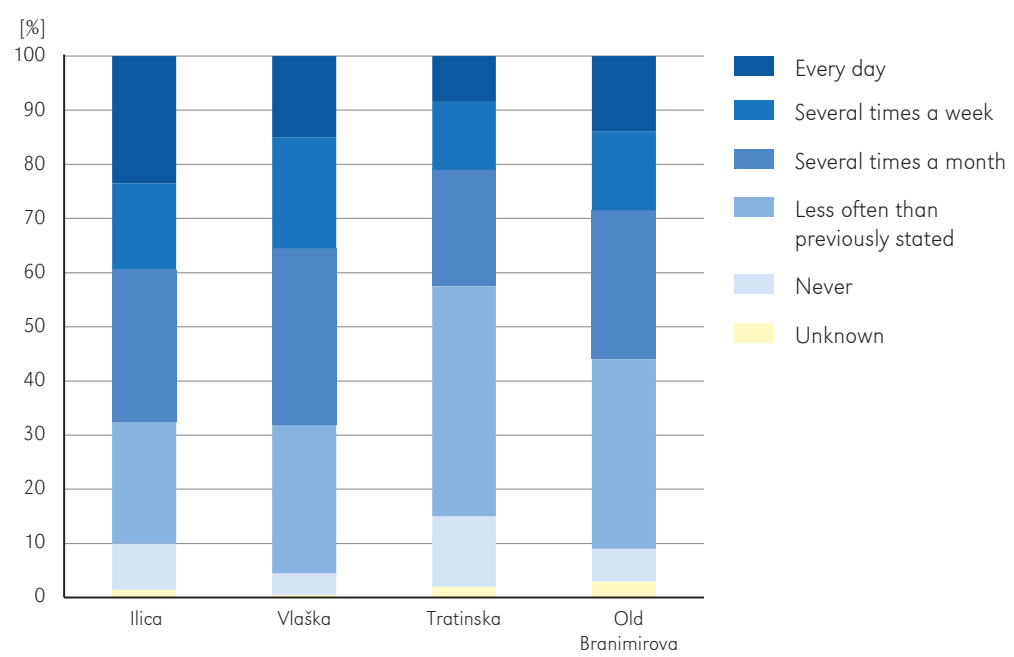

Figure 2. Frequency of visiting researched streets

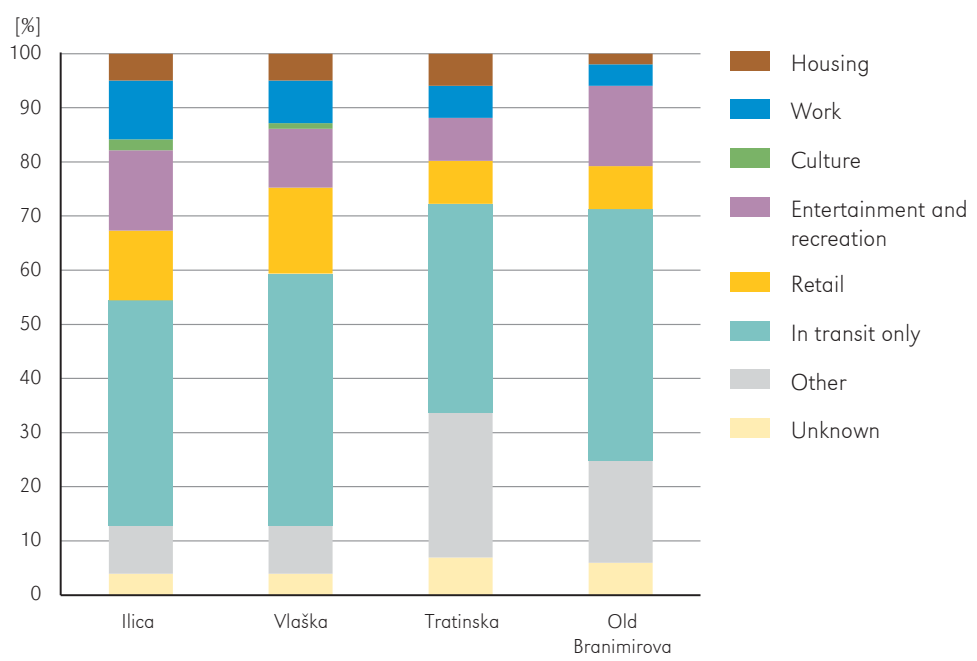

Figure 3. Respondents' reasons for visiting researched streets (refers to the online part of research only)

One in four respondents expected that redevelopment or renovation would take place and that at least part of such premises would be returned to use: 'Apartments and small shopping centres will be built' (R-066); 'Other stores will open in some of them, and the rest will remain vacant' (R-065); and 'They will be leased to someone else, bars and restaurants (especially on llica)' (R-171).

Respondents (11.5\%) also expressed their hope for positive changes, which is illustrated by the following answers: 'I believe the city government will adopt regulations to encourage everything that is missing in certain neighbourhoods. In my opinion, they should first adopt universal regulation of commercial spaces' lease rates [...]. In parallel, legislation regarding exemption from duties for deficit businesses should be adopted' (R-055); 'I hope they will be renovated or at least a bit enhanced so they are no longer an eyesore' (R-070); 'I hope the [C]ity will recognise the value of such premises and provide incentives to traditional trade and craft 
Table 3. Possible changes for vacant commercial premises in the researched streets in the following 10 years, according to the respondents ${ }^{\star}$

\begin{tabular}{|c|c|c|}
\hline Changes expected in the following 10 years & $\begin{array}{l}\text { Number } \\
\text { of coded } \\
\text { answers }\end{array}$ & $\begin{array}{l}\% \text { of } \\
\text { respondents }\end{array}$ \\
\hline $\begin{array}{l}\text { Changes are not expected, i.e. vacant premises will keep deteriorating or their } \\
\text { number will increase }\end{array}$ & 73 & 36.5 \\
\hline $\begin{array}{l}\text { Redevelopment or renovation and reuse of at least some of the properties } \\
\text { is expected }\end{array}$ & 50 & 25.0 \\
\hline Hope for positive changes & 23 & 11.5 \\
\hline $\begin{array}{l}\text { Stagnation or continued deterioration is expected, unless revitalisation measures } \\
\text { are taken }\end{array}$ & 21 & 10.5 \\
\hline Respondent did not know & 9 & 4.5 \\
\hline They will be repurchased at low prices by privileged investors and redeveloped & 6 & 3.0 \\
\hline Other & 14 & 7.0 \\
\hline Total & 196 & \\
\hline
\end{tabular}

* $4(2.0 \%)$ respondents did not provide answers.

shops, young designers, and interesting hospitality services [...]' (R-090); 'If the economic situation in the country improves, maybe there is a chance that these premises will be revitalised' (R-181); 'New jobs will be created if people show entrepreneurial spirit.' (R-195).

Some of the respondents were concerned that abandoned property would be bought at low prices by privileged investors, and redeveloped. 'Large investors will wait in an attempt to drop the prices and have the current tenants move out in order to buy such properties at low prices, demolish them and build commercial premises and shopping centres' (R-058).

When asked about what activities would be suitable at the locations of currently vacant premises, the respondents had the possibility to choose multiple answers (Fig. 4). Over $60 \%$ of the respondents chose student amenities and cultural activities, followed by artistic programmes, hospitality services, small and medium-sized enterprises (such as incubators and co-working spaces), retail stores, and civil society organisations. Bakeries, residential housing, and other activities were placed at the bottom.

Finally, when asked about the role of the City of Zagreb regarding the vacant commercial premises in the city centre, $89.5 \%$ of the respondents agreed that the City should financially support their redevelopment and use. Among other potential measures, the respondents mentioned the possibility to penalise passive owners, encourage the redevelopment of property, and resolve property-related legal issues:

'Penalise the owners of vacant premises if they do not return such property to use within a certain period and, at the same time, encourage its redevelopment financially, but only if it makes sense on the basis of previously-conducted research, and the needs of the citizens, and developmental needs.' (R-012);

'[W]ith financial support, repurchase part of such property and offer it to civil and cultural organisations for use' (R-017);

'Provide special conditions to people who continue to engage in trades and crafts that are still necessary' (R-081);

'First of all, resolve property-related legal issues, because $60 \%$ of them do not have this resolved. [A]fter this is done, we can talk about some redevelopment [...]' (R-021);

Only $1.5 \%$ of the respondents believed that the City of Zagreb should not do anything regarding the vacant premises in the city centre. 


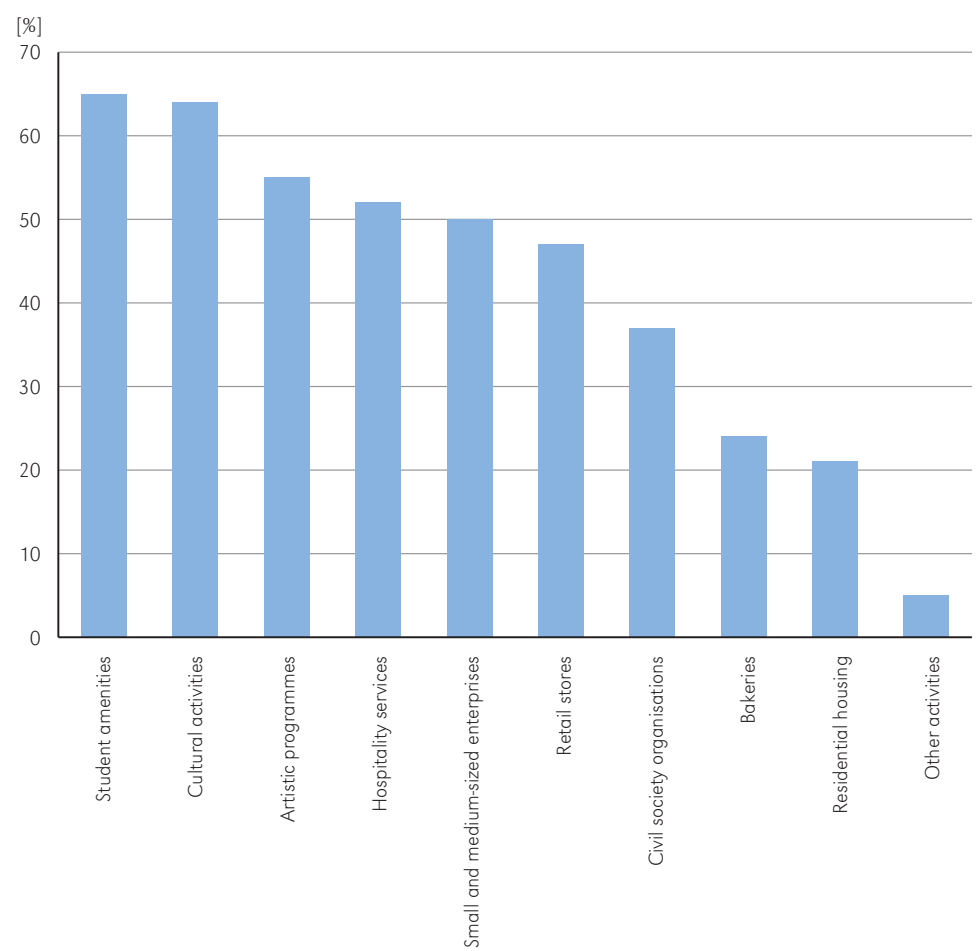

Figure 4. Functions and activities suitable for vacant commercial premises, according to the respondents

$\star 1(0.5 \%)$ respondent did not provide answers.

\section{Discussion and conclusion}

Respondents in this research - citizens of Zagreb - can be understood as the users and (co)creators of urban space, and an interested party in its future development and governance. Almost three-fourths of them believed that the centre of Zagreb contained a large number of vacant commercial premises. The majority of them thought the same about the four streets examined in this study, where a total of 206 vacant commercial premises were mapped. According to the respondents, the main reasons for contemporary negative processes taking place in the wider city centre included financial reasons (first of all high rent), followed by reasons related to economic development such as the economic crisis, unemployment, and reduced purchasing power. Regardless of population decline in some of the centrally located neighbourhoods in Zagreb, recorded in the 2001-2011 intercensal period (Valožić, Radeljak, \& Grbac Žiković, 2012), and the emigration trend following the start of the financial crisis in 2008/2009 and Croatia joining the EU in 2013, among reasons for abandonment, respondents gave less importance to the demographic aspect and emigration. In contrast, the decentralisation of certain city (retail) functions to the periphery was seen as a significant factor for the abandonment of commercial premises (Compare with Gorter et al., 2003; Jakovčić, 2006). The loss of importance of traditional shops that could no longer compete with the modern trends on the market was also viewed as important; the perceived lack of good business management is closely connected with this. Around one in three respondents who remembered the researched streets for their former activities and use associated them specifically with 
small stores and traditional trade and craft shops such as shoemakers, tailors, clockmakers, quilters, hatters, etc. The issue of revival of vacant premises in Zagreb thus opens the question of revitalisation of former workshops and commercial premises (at least partially) in the form of traditional crafts and classic trades that once served as identifiers for various parts of the city centre. Other reasons for abandoning commercial premises listed by the respondents to a great extent correspond to the findings from previous studies, especially in regard to the post-socialist cities (e.g. specific problems related to transition and governance issues), with an exception - there was no mention of online shopping (See: Dolega \& Lord, 2020; Kita et al., 2017).

The urban core shopping area can be seen as one of key elements in how citizens perceive the urban space (Nagy, 2001). Therefore, the problem of vacant commercial premises can be observed from the point of view of the specific "spirit of the place" and urban identity that is related to the city centre as an area where daily life takes place (Tonković, 2015, 12). Respondents had differing opinions regarding the statement that Zagreb's city centre no longer has the function of social meeting place that it used to have, with $48.0 \%$ of respondents agreeing with this statement. Furthermore, it is indicative that the majority of the respondents (63.5\%) agreed that the vacant commercial premises in the city centre reduce the appeal of these areas for recreational, hospitality, and other activities from the service sector. On the other hand, respondents were of the opinion that the diversification of services and activities would attract visitors to the city centre and that the revitalisation of vacant premises would contribute to the development of tourism in Zagreb.

When we analyse the reasons for which respondents came to the researched streets, the dominant reason was the same - the respondents did not come for a specific purpose, they were only passing through. However, there is no doubt that the circulation of citizens and visitors to these locations remains constant, which is relevant for the wider context of urban regeneration. A large share of respondents (over 60\%) believed that student-oriented amenities and cultural activities would be suitable for vacant commercial premises (unsurprising considering the overrepresentation of young people and underrepresentation of seniors among respondents), followed by other activities depending on the needs and circumstances of individual areas. More than one in three respondents was of the opinion that vacant premises will keep deteriorating or that their number will increase.

Nevertheless, respondents also largely disagreed with the statement that vacant premises did not require redevelopment or revitalisation. This confirms the fact that respondents see vacant spaces as a real problem, which requires real intervention. City administration or the way the city is governed was seen as both a cause and a solution to the problem, i.e. it was listed among the reasons for abandonment of commercial premises, but its role was seen as especially important in relation to potential future development and approaches to regeneration. According to respondents, the City should undertake active revitalisation measures, encourage redevelopment and utilisation of vacant premises, both financially and by granting conditional easements, lowering lease rates, attempting to resolve propertyrelated legal issues, and even penalising owners in certain cases - for example, if a vacant space is not returned to use. This outlook on the role of the City leads to the conclusion that respondents favour a stronger regulatory framework, which would set the rules for transparent and functional revitalisation of vacant commercial premises (including specificities of individual locations) within a strategic approach to urban regeneration.

Attention has already been drawn to the problem of the lack of coherent strategy and vision for city development in Zagreb, which leads to the non-systematic treatment of urban spaces (Svirčić Gotovac, 2010). Importance of strategic plans defining overall 
objectives of city centre revitalisation (Tonković, 2015) and of strategic interventions in the scope of comprehensive urban regeneration is highlighted for post-socialist cities in general (Keresztély \& Scott, 2012). A higher level of participation in the urban regeneration processes is also called for (Compare with Svirčić Gotovac \& Kerbler, 2019). If a multi-faceted concept like public interest is taken into account, as an agreement among social groups aimed at protecting the existing image of the place and the identity of the environment (Mihajlov, 2009), the roles of different actors are stressed, including the local administration, companies, schools, business networks, local organisations, and citizens (Hospers, 2014).

In this study, the results of mapping at selected locations demonstrated the existence and functional structure of vacant commercial premises on the researched streets in Zagreb's city centre, providing a sound basis for further exploration of the issue. The results of the questionnaire survey showed that respondents recognised the nuances of the problem at the level of selected locations and the wider city centre. This includes the awareness of the complex set of reasons underlying the occurrence and expansion of this phenomenon in the centre of Zagreb and the need for urban regeneration, which would integrate effective interventions to preserve the wider city centre as an area for the various, everyday functions of its inhabitants.

Finally, further research could include an expanded sample of citizens and different groups of stakeholders. Moreover, studies could include analyses of the underlying reasons for abandoning commercial premises in city centres at more detailed scales (such as the level of individual properties), as well as differences between daytime and nighttime populations.

\section{Acknowledgements}

The main part of this research was undertaken in the course of the class on Methods and Techniques of Regional and Spatial Planning in the 2015/2016 academic year and with the cooperation of Association "Cyclists' Union". The research work was continued in 2017 by the co-authors of this paper.

\section{Editors' note:}

Unless otherwise stated, the sources of tables and figures are the authors', on the basis of their own research.

\section{References}

Adams, D., Disberry, A., Hutchison, N., Munjoma, T. (2002). Retail location, competition and urban redevelopment. The Service Industries Journal, 22(3), 135-148. https://doi.org/10.1080/714005090

Bilková, K., Križan, F., Barlík, P. (2016). Consumers preferences of shopping centers in Bratislava (Slovakia). Human Geographies - Journal of Studies and Research in Human Geography, 10(1), 23-37. https://doi.org/10.5719/hgeo.2016.101.2

Čaldarović, O., Šarinić, J. (2008). First signs of gentrification? Urban regeneration in the transitional society: The case of Croatia. Sociologija i prostor, 46(3-4), 369-381.

Črnjar, M., Rodin, V. (2016). Prostorni i ekonomski aspekti urbane regeneracije - iskustva o napuštenim građevinama u PGŽ. In A. Korlaet (ed.), Strategije urbane regeneracije/Urban regeneration strategies (pp. 328-336). Zagreb: Croatian Institute for Spatial Development.

Damurski, Ł., Pluta, J., Maier, K., Andersen, H.T. (2019). Stakeholders in the local service centre: Who should be involved in the planning process? Insights from Poland, Czech Republic and Denmark. Bulletin of Geography. Socio-economic Series, 43(43), 91-106. https://doi.org/10.2478/bog-2019-0006 
Dembski, S., Sykes, O., Couch, C., Desjardins, X., Evers, D., Osterhage, F., Siedentop, S., Zimmermann, K. (2019). Reurbanisation and suburbia in Northwest Europe: A comparative perspective on spatial trends and policy approaches. Progress in Planning, 100462. https://doi.org/10.1016/j.progress.2019.100462

Dolega, L., Lord, A.L. (2020). Exploring the geography of retail decline: A case study of the Liverpool City. Cities, 96, 102456. https://doi.org/10.1016/j.cities.2019.102456

Doratli, N. (2005). Revitalizing historic urban quarters: A model for determining the most relevant strategic approach. European Planning Studies, 13(5), 749-772. https://doi.org/10.1080/09654310500139558

Dumbović-Bilušić, B. (2016). Urbana obnova povijesnih cjelina. In A. Korlaet (ed.), Strategije urbane regeneracije/Urban Regeneration Strategies (pp. 82-90). Zagreb: Croatian Institute for Spatial Development.

Ferretti, V., Grosso, R. (2019). Designing successful urban regeneration strategies through a behavioral decision aiding approach. Cities, 95, 102386. https://doi.org/10.1016/j.cities.2019.06.017

Geoportal. (2019). Geoportal Državne geodetske uprave/ Geoportal of the State Geodetic Administration. Retrieved from https://geoportal.dgu.hr/. [19 November 2019].

Gorter, C., Nijkamp, P., Klamer, P. (2003). The attraction force of out-of-town shopping malls: A case study on run-fun shopping in the Netherlands. Tijdschrift voor economische en sociale geografie, 94(2), 219-229. https://doi.org/10.1111/1467-9663.00250

Grad Zagreb, Gradski ured za strategijsko planiranje i razvoj grada Zagreba/City of Zagreb, City office for the strategic planning and development of the city: ZagrebPlan: Razvojna strategija Grada Zagreba, strateška razvojna usmjerenja do kraja 2013 godine. Retrieved from https://www.zagreb.hr/UserDocs/mages/arhiva/zgplan/zgplan.pdf [10 November 2019].

Grad Zagreb, Gradski ured za strategijsko planiranje i razvoj Grada Zagreba/City of Zagreb, City office for the strategic planning and development of the city: Razvojna strategija Grada Zagreba za razdoblje do 2020. godine. Retrieved from https://www.zagreb.hr/UserDocslmages/gu\%20za\%20strategijsko\%20planiranje/Razvojna\%20strategija\%20Grada\%20Zagreba_SGGZ_18-17.pdf. [20 September 2019].

Guimarães, P.P.C. (2018). Town centre management: Outlook from Portugal. Planning Practice \& Research, 33(1), 18-33. https://doi.org/10.1080/02697459.2017.1378967

Guy, C.M. (1998). Controlling new retail spaces: The impress of planning policies in Western Europe. Urban Studies, 35(5-6), 953-979. https://doi.org/10.1080/0042098984637

Haase, A., Bernt, M., Großmann, K., Mykhnenko, V., Rink, D. (2013). Varieties of shrinkage in European cities. European Urban and Regional Studies, 23(1), 86-102. https://doi.org/10.1177/0969776413481985

Hall, P. (2002). Urban and regional planning. London: Routledge.

Hebar, Z. (2016). Iskustva u planiranju, projektiranju i realizaciji prostora urbane regeneracije. In A. Korlaet (ed.), Strategije urbane regeneracije/Urban Regeneration Strategies (pp. 162-177). Zagreb: Croatian Institute for Spatial Development.

Hospers, G.J. (2014). Policy responses to urban shrinkage: From growth thinking to civic engagement. European Planning Studies, 22(7), 1507-1523. https://doi.org/10.1080/09654313.2013.793655

Ianoş, I., Sorensen, A., Merciu, C. (2017). Incoherence of urban planning policy in Bucharest: Its potential for land use conflict. Land Use Policy, 60, 101-112. https://doi.org/10.1016/j.landusepol.2016.10.030

Jakovčić, M. (2006). Business Functions and Problem of Closure of Commercial Premises in Ilica Street in Zagreb. Hrvatski geografski glasnik, 68(1), 27-50. https://doi.org/10.21861/HGG.2006.68.01.02

Jakovčić, M., Franz, Y., Buzjak, N. (2016). Usporedba pristupa urbanoj regeneraciji Zagreba i Beča. In A. Korlaet (ed.), Strategije urbane regeneracije/Urban Regeneration Strategies (pp. 90-99). Zagreb: Croatian Institute for Spatial Development. 
Jukić, T. (2016). Urbana regeneracija - posljedica ili preventiva. In A. Korlaet (ed.), Strategije urbane regeneracije/Urban Regeneration Strategies (pp. 50-58). Zagreb: Croatian Institute for Spatial Development.

Kaczmarek, S. (2019). Ruining, demolition and regeneration in urban space: Sketching the research problem. Geographia Polonica, 92(1), 5-16. https://doi.org/GPol.0133

Keresztély, K., Scott, J.W. (2012). Urban regeneration in the post-socialist context: Budapest and the search for a social dimension. European Planning Studies, 20(7), 1111-1134. https://doi.org/10.1080/09654313.2012.674346

Kita, P., Szczyrba, Z., Fiedor, D., Létal, A. (2018). Recognition of business risks when purchasing goods on the Internet using GIS: Experience from Slovakia. Electronic Commerce Research, 18(3), 647-663. https://doi.org/10.1007/s10660-017-9276-5

Križan, F., Bilková, K., Kita, P., Siviček, T. (2016). Transformation of retailing in post-communist Slovakia in the context of globalization. E+M Ekonomie a management, 19(1), 148-164. https://doi.org/10.15240/tul/001/2016-1-011

Kunc, J., Frantál, B., Szczyrba, Z., Tonev, P., Toušek, V. (2011). Shopping centres and shopping behaviour: selected relations and socio-geographical implications (The Vaňkovka Gallery Brno, Czech Republic example). Acta Universitatis Palackianae Olomucensis Facultas Rerum Naturalium-Geographica, 42(1), 5-17.

Kunc, J., Križan, F. (2018). Changing European retail landscapes: New trends and challenges. Moravian Geographical Reports, 26(3), 150-159. https://doi.org/10.2478/mgr-2018-0012

Lukić, A. (2002). Socijalne funkcije trgovačko-poslovnog središta: primjer Centra Kaptol u Zagrebu. Hrvatski geografski glasnik, 64, 73-94.

Lukić, A., Jakovčić, M. (2004). Location and function of hypermarkets and shoping centres in Zagreb. Dela, (22), 39-54. https://doi.org/10.4312/dela.22.39-54

Matković, I. (2016). Strategije urbane regeneracije. In A. Korlaet (ed.), Strategije urbane regeneracije/ Urban Regeneration Strategies (pp. 8-16). Zagreb: Croatian Institute for Spatial Development.

Mihajlov, V. (2009). Socijalni motivi i efekti regeneracije industrijskog nasljeđa. Sociologija i prostor, 47(2), 139-164.

Nagy, E. (2001). Winners and losers in the transformation of city centre retailing in East Central Europe. European Urban and Regional Studies, 8(4), 340-348. https://doi.org/10.1177/096977640100800406

Narodne novine (2017). Strategija prostornog razvoja Republike Hrvatske. Retrieved from https://narodne-novine.nn.hr/clanci/sluzbeni/2017_10_106_2423.html [5 October 2019].

Petrić, L., Mikulić, D. (2009). Uloga kulturnog turizma u procesu urbane regeneracije. Acta turistica nova, 3(1), 5-26.

Poljičak, I. (2014). Utjecaj suvremenog kulturnog turizma na promjene načina života u starim gradskim jezgrama na hrvatskoj obali. Zbornik radova Veleučilišta u Šibeniku, (1-2), 83-89.

Pretković, M. (2013). Tvornica "Nada Dimić" u Zagrebu - povijesni pregled, problemi zaštite i mogućnosti revitalizacije. Godišnjak zaštite spomenika kulture Hrvatske, 37/38, 119-132.

Scott, J.W., Kühn, M. (2012). Urban change and urban development strategies in Central East Europe: A selective assessment of events since 1989. European Planning Studies, 20(7), 1093-1109. https://doi.org/10.1080/09654313.2012.674345

Sić, M. (2007). Spatial and functional changes in recent urban development of Zagreb. Dela, (27), 5-15. https://doi.org/10.4312/dela.27.5-15

Slavuj, L., Cvitanović, M., Prelogović, V. (2009). Emergence of problem areas in the urban structure of post - socialist Zagreb. Spatium, 21, 76-83.

Stanilov, K. (2007a). Urban development policies in Central and Eastern Europe during the transition period and their impact on urban form. In K. Stanilov (ed.), The post-socialist city: Urban form and space transformations in Central and Eastern Europe after socialism (pp. 347-361). Dordrecht: Springer. 
Stanilov, K. (2007b). Taking stock of post-socialist urban development: A recapitulation. In K. Stanilov (ed.) The post-socialist city: Urban form and space transformations in Central and Eastern Europe after socialism (pp.3-17). Dordrecht: Springer.

Spilková, J., Radová, L. (2011). The formation of identity in teenage mall microculture: A case study of teenagers in Czech malls. Czech Sociological Review, 47(3), 565-586.

Subiza-Pérez, M., Vozmediano, L., San Juan, C. (2020). Welcome to your plaza: Assessing the restorative potential of urban squares through survey and objective evaluation methods. Cities, 100. https://doi.org/10.1016/j.cities.2019.102461

Svirčić Gotovac, A. (2010). Aktualni revitalizacijski i gentrifikacijski procesi na primjeru Zagreba. Sociologija i prostor, 48(2), 197-221.

Svirčić Gotovac, A., Kerbler, B. (2019). From post-socialist to sustainable: The city of Ljubljana. Sustainability, 11(24). https://doi.org/10.3390/su11247126

Sýkora, L., Bouzarovski, S. (2012). Multiple transformations: Conceptualising the post-communist urban transition. Urban Studies, 49(1), 43-60. https://doi.org/10.1177/0042098010397402

Temelová, J. (2007). Flagship developments and the physical upgrading of the post-socialist inner city: The golden angel project in Prague. Geografiska Annaler: Series B, Human Geography, 89(2), 169-181. https://doi.org/10.1111/j.1468-0467.2007.00246.x

Trembošová, M, Dubcová, A., Kramáreková, H. (2016). Consumers shopping behaviour in the Nitra city. The Agri-Food Value Chain: Challenges for Natural Resources Management and Society, 128, 836-849. http://dx.doi.org/10.15414/isd2016.s10.09

Tonković, Ž. (2015). Trgovački centri i promjene u gradskoj jezgri: slučaj Zadra. Sociologija i prostor, 53(1), 3-20. https://doi.org/10.5673/sip.53.1.1

Valožić, L., Radeljak, P., Žiković, R. (2012). Prostorna analiza upisnih područja osnovnih škola u Gradu Zagrebu, Hrvatski geografski glasnik, 74(2), 27-51. https://doi.org/10.21861/HGG.2012.74.02.02

ZIS. (2019). Zajednički informacijski sustav zemljišnih knjiga i katastra/ Joint Land Registry and Cadastre Information System. Retrieved from https://oss.uredjenazemlja.hr/public/IrServices. jsp?action=publicLdbExtract [10 October 2019]. 